University of South Carolina

Scholar Commons

$6-17-2011$

\title{
Media Attention on African Americans with Human Immunodeficiency Virus
}

Charles S. Beverley Jr.

University of South Carolina - Columbia

Edith M. Williams

University of South Carolina - Columbia, willi425@mailbox.sc.edu

Saundra H. Glover

University of South Carolina - Columbia

Follow this and additional works at: https://scholarcommons.sc.edu/

sph_epidemiology_biostatistics_facpub

Part of the Public Health Commons

\section{Publication Info}

Published in Environmental Justice, ed. Sylvia Hood Washington, Volume 4, Issue 2, 2011, pages 135-138. This is a copy of an article published in Environmental Justice ( 2011 Mary Ann Liebert, Inc.; Environmental Justice is available online at: http://online.liebertpub.com. Beverley, C.S., Williams, E.M., \& Glover, S.H. (2011) Media Attention on African Americans with Human Immunodeficiency Virus. Environmental Justice 4(2), 135-138.

This Article is brought to you by the Epidemiology and Biostatistics at Scholar Commons. It has been accepted for inclusion in Faculty Publications by an authorized administrator of Scholar Commons. For more information, please contact digres@mailbox.sc.edu. 


\title{
Media Attention on African Americans with Human Immunodeficiency Virus
}

\author{
Charles S. Beverley, Jr., Edith M. Williams, and Saundra H. Glover
}

\begin{abstract}
Human immunodeficiency virus (HIV) is a disease that has captured the attention of the media in various ways and to varying degrees. One of the ongoing debates and areas of research in HIV that provide many opportunities for discovery is the disproportionate number of African Americans infected with HIV compared to the amount of attention they receive in the media. This manuscript addresses the question that has preoccupied the minds of many people: Why have African Americans infected with HIV received so little media attention? Analysis of this question suggests that there are many reasons for this lack of media attention. One reason in particular is the media tends to be much less attentive to diseases, such as HIV, that disproportionately burden blacks relative to whites. We also find that the media is reluctant to write about HIV in African Americans because it portrays them negatively. The media suggests that people are bombarded with negative news about African Americans and writing about them with regard to HIV only reinforces the negative. Finally, analysis reveals that in recent years African Americans with HIV have received more media attention due to the increase in rates of HIV in African Americans. This increase in media attention helps educate African Americans about the disease, reduces the stigma associated with it, and inspires African Americans to get tested and linked to care. In this way, African Americans with HIV can help the community stay virus-free.
\end{abstract}

\section{INTRODUCTION}

$\mathbf{T}$ HE HUMAN IMMUNEDEFICIENCY VIRUS (HIV) is a retrovirus that causes acquired immunodeficiency syndrome (AIDS) by infecting helper $\mathrm{T}$ cells of the immune system. ${ }^{1}$ HIV belongs to a subset of retroviruses called lentiviruses or slow viruses, which means that there is an interval, sometimes years between the initial infection and the onset of symptoms. Upon entering the bloodstream through mucous membranes or blood-to-blood contact, HIV infects the helper $\mathrm{T}$ cells and begins to replicate rapidly. ${ }^{2}$ When the virus enters the body, HIV begins to disable the body's immune system by using the body's aggressive immune responses to the virus to infect, replicate, and kill the immune system cells. Gradual deterio-

Mr. Beverley, Dr. Williams, and Dr. Glover are with the Institute for Partnerships to Eliminate Health Disparities, Arnold School of Public Health, University of South Carolina.

${ }^{1}$ Wikipedia contributors. "HIV." Wikipedia, The Free Encyclopedia. Aug. 10, 2010. <http://en.wikipedia.org/wiki/Hiv>. (Last accessed on Aug. 12, 2010).

${ }^{2} \mathrm{Ibid}$. ration of immune function and eventual destruction of lymphoid and immunologic organs is central to triggering the suppression of the immune system that leads to AIDS. ${ }^{3}$

HIV was first recognized as a disease in 1981 and has since become a worldwide pandemic. For instance, African Americans represented 50\% of the U.S. population affected by HIV in 2009, and that percentage is constantly increasing. ${ }^{4}$ One of the ongoing debates and areas of research that provide many opportunities for discovery is the disproportionate number of African Americans infected with HIV compared to the amount of attention they receive in the media. Brodie (2004) found that only $3 \%$ of stories in the media are about U.S. minorities with HIV. ${ }^{5}$ These findings are alarming

\footnotetext{
${ }^{3}$ T. Paustian and G. Roberts. Through the microscope: A look at all things small. (Lulu.com, 2006).

${ }^{4}$ M. Williams. "HIV Issues: African American Women at Risk." EPIGEE. Apr. 5, 2009. < http://www.epigee.org/health/hiv_aa html>. (Last accessed on Nov. 16, 2009).

${ }^{5}$ M. Brodie, E. Hamel, L. A. Brady, J. Kates, and D. E. Altman, "AIDS at 21: Media Coverage of the HIV Epidemic 1981-2002," Columbia Journalism Review 1 (2004 suppl): 1-8.
} 
because the Centers for Disease Control and Prevention (CDC) (2006) estimates that from 1981 through 1995, African Americans accounted for $34.6 \%$ of the estimated percentage of persons living with HIV in the United States, compared to $46.5 \%$ for whites, and $17.9 \%$ for Hispanic. ${ }^{6}$ From 1996 through 2000, African Americans made up over $47 \%$, a 12.4 percentage point increase from 1981 through 1995, of those living with HIV in the United States. During this period, whites accounted for $31.6 \%$ and Hispanics accounted for $20.3 \%$, a 14.9 percent point decrease and a 2.4 percent point increase, respectively. From 2001 through 2004, the estimated percentage of persons living with HIV in the United States increased to $49.5 \%$ for African Americans, decreased to $28.3 \%$ for whites, and remained the same for Hispanics at 20.3\%. From 2004 through 2006, African Americans accounted for $48 \%$ of persons estimated to be living with HIV in the United States, compared to $34.6 \%$ of whites and $17.5 \%$ of Hispanics. From 1981 through 2006, the trend in the estimated percentage of persons to be living with HIV showed an overall 13.4 point increase for African Americans, an 11.9 point decrease for whites, and a 0.4 point decrease for Hispanics. $^{7}$

Kitahata et al. (2009) suggests that the estimated percentage of persons living with HIV has increased so much more for African Americans because of antiretroviral treatment. ${ }^{8}$ This treatment has greatly extended the life spans of the growing population of persons infected with HIV. As more African Americans become infected with HIV, fewer die from the disease each year because the antiretroviral treatment not only extends life expectancy, but also slows progression of HIV to AIDS. Kitahata et al. also suggests that a reason for the decrease in the estimated percentage of whites and Hispanics living with HIV since 1981 may have been due to antiretroviral treatment being initiated later in the course of their HIV infection. ${ }^{9}$ Overall, the statistics indicate that since 1981 the estimated percentage of persons living with HIV has increased more for African Americans than for whites and Hispanics, which begs the question, why have African Americans infected with HIV received so little media attention?

\section{DISCUSSION}

Armstrong et al. (2006) argues that the reason African Americans infected with HIV have received little media attention is because diseases, such as HIV, that affect African Americans or other minority groups more than

${ }^{6}$ CDC. Twenty-Five Years of HIV/AIDS-United States, 19812006. (Morbidity and Mortality Weekly Report, 2006).

${ }^{7}$ Ibid.

${ }^{8}$ M. M. Kitahata, S. J. Gange, A. G. Abraham, B. Merriman, M. S. Saag, A. C. Justice, et al., "Effect of Early versus Deferred Antiretroviral Therapy for HIV on Survival," The New England Journal of Medicine 360 (2009): 1815-1826.

${ }^{9}$ Ibid. whites are regarded as less salient and pose a lesser threat to the general population. ${ }^{10}$ News media reduces the agenda space granted to these types of diseases, thus diminishing public attention to African Americans with HIV. ${ }^{11}$ Brodie et al. agrees with Armstrong and argues that the biggest television and print news story about an African American with HIV was Magic Johnson's announcement that he was HIV positive. ${ }^{12}$ However, only $16 \%$ of television and print news stories in the U.S. were about Magic Johnson's announcement. This indicates that even this story was given a small agenda space. Similarly, between 1991 and 1993, the media covered tennis player Arthur Ashe's death from AIDS, but only 5\% of television and print news stories in the U.S. were about his death. This also indicates that the story was given a small agenda space. ${ }^{13}$ There is no evidence to support why this pattern occurs, however it may result from the efforts of the predominantly white management of newspapers and broadcast outlets to accommodate the interests and concerns of their own group.

Volin (2006) argues that the reason for the lack of agenda space and mainstream television and print media coverage of African Americans with HIV is due to apathy from the general public about the concerns of minorities. ${ }^{14}$ When stories about African Americans with HIV make the news they do not cause outrage or any type of community reaction from the church, families, or even within the African American community, and thus, these messages do not hold the sensationalism desired by the media. ${ }^{15}$ When the media does report on African Americans with HIV, the depictions are negative and primarily about African American homosexual and bisexual men. ${ }^{16}$ These stories often irresponsibly and inaccurately depict these men as deceitful by equating them to men who proclaim to be heterosexual while privately engaging in same gender sexual relationships. ${ }^{17}$ There are not many affirming messages in the media about African American homosexual and bisexual men, and as a result, these media depictions only add to the negative ways African American homosexual and bisexual men view themselves and are viewed by society.

Goldman (2008) acknowledges that in her interactions with television and print media, she found that they are reluctant to write about HIV in African Americans because it portrays them in a negative light. The media feels that people are bombarded with negative news about

\footnotetext{
${ }^{10}$ E. M. Armstrong, D. P. Carpenter, and M. Hojnacki, “Whose Deaths Matter? Mortality, Advocacy, and Attention to Disease in the Mass Media," Journal of Health Politics, Policy and Law 31 (2006): 729-772.

${ }^{11}$ Ibid.

${ }^{12}$ Brodie et al., "AIDS at 21," 1-8.

${ }^{13}$ Ibid.

${ }^{14} \mathrm{~K}$. Volin, "Ignoring an epidemic? AIDS activists decry media coverage of disease among black gay men," Washington Blade, June 1, 2006. [1].

${ }^{15}$ Ibid.

${ }^{16} \mathrm{Ibid}$.

${ }^{17}$ Ibid.
} 
African Americans, such as crime and poverty. ${ }^{18}$ It is believed that messages concerning HIV would further reinforce that negative image. Moreover, some are of the opinion that African Americans would feel like the media was blaming them for the disease if more news stories were written about them. However, Goldman argues that the media's decision not to write more stories about African Americans with HIV is not wise. She feels that it keeps up a barrier, or "wall of silence," that hinders dialogue and discussion in the African American community about pertinent issues regarding the disease, such as its stigma. ${ }^{19}$ HIV stigma refers to prejudice, negative attitudes, abuse, and maltreatment directed at people living with HIV. This can manifest itself as being shunned by family, peers, and the wider community; poor treatment in healthcare and education settings; an erosion of rights; and psychological damage. $^{20}$ This stigma can cause African Americans to view the disease as a form of punishment.

Howard (1991) suggests that the reason African Americans with HIV merit so little television and print media attention is because of this view of HIV as a punishment. ${ }^{21}$ Such views, Howard posits, compel many in the black media to take a defensive stance in covering the virus. As a result, many publishers do not choose to cover the specifics of the virus as it relates to African Americans. ${ }^{22}$ Another reason African Americans with HIV merit so little media attention is because many ethnic publishers and broadcasters do not have the advertising revenues to support the hiring of scientific and technological reporters to investigate specific HIV issues as they relate to African Americans, unlike their white counterparts in mainstream media. $^{23}$ Additionally, many ethnic publishers and broadcasters are reluctant to cover HIV in African Americans because to do so calls for discussion of sensitive topics such as drugs and sex. Given their strong base in the church, many ethnic publishers and broadcasters have had pressure placed upon them not to discuss the issues related to the transmission of HIV, such as analgenital sex, condom use, and drugs. ${ }^{24}$

The unwillingness of television and print media to focus attention on African Americans with HIV conveys that their focus is in other areas, specifically on HIV issues that affect the general population and not minorities in particular. Brodie et al. argues that HIV is a dominant topic of news stories that have changed over time in that they focus more on the general population and are widely distributed among different categories. The most wellknown category, which made up $13 \%$ of stories overall,

\footnotetext{
${ }^{18}$ B. Goldman. "Race Relations Expert Laments Poor Media Coverage of HIV, Homosexuality Among Blacks." African American HIV Resource Center: Movers and Shakers. Mar. 21, 2008. <http://www.thebody.com/content/art45876.html >. (Last accessed on Nov. 29, 2009).

${ }^{19}$ Ibid.

${ }^{20}$ Ibid.

${ }^{21} \mathrm{M}$. Howard, "Have the Black and Latino Media Dropped the Ball on Covering HIV?" Aids Patient Care 5 (1991): 54-55.

${ }^{22}$ Ibid.

${ }^{23}$ Ibid.

${ }^{24} \mathrm{Ibid}$.
}

was HIV prevention. This category consisted of stories about HIV education and awareness. These stories were followed by $11 \%$ of stories concerning research, including research on HIV drugs, treatments, and vaccines. On average, one in ten stories concerned HIV transmission, and another one in ten centered on social issues such as discrimination and housing for people with HIV. ${ }^{25}$ However, from 2000 to 2002, stories about social issues such as discrimination and housing declined from $15 \%$ to $4 \%$, and HIV testing stories declined from $7 \%$ to $2 \%$. Nevertheless, stories about government funding/financing for HIV increased from $7 \%$ to $18 \%$, which included stories concerning the cost of prescription drugs and those about philanthropic fundraising efforts. ${ }^{26}$ It can be inferred from these statistics that although the media did not focus a lot of attention on African Americans with $\mathrm{HIV}$, they did a great service, in general, to communities infected with HIV because they focused on HIV stories that affected the general population. For this reason, Brodie believes that African Americans still benefitted from the impact of these stories, even if indirectly. ${ }^{27}$

Spence (2009) argues that the way African Americans are covered by print media in regards to HIV has indeed changed significantly from them being invisible to highly visible. ${ }^{28}$ Spence conducted an Ethnic Newswatch search for "HIV" relegating the search to newspaper and magazine articles dealing with African American/Caribbean/ African subjects and it revealed 1,593 newspaper articles in the black press between January 1, 1991 and December 31,2001 . Spence concluded that this was more than a $40-$ fold increase compared to the same period ten years earlier in 1981. Using the same method and restricting the search to a narrower range of dates (January 1, 2002December 31, 2005) revealed 2,467 newspaper and magazine articles, which was more than an 80 -fold increase within a much shorter period of time. ${ }^{29}$

Spence suggests that the reason for this increase in attention on African Americans with HIV is due to increasing rates of HIV infection in African Americans. CDC (2005) estimated that of the newly diagnosed HIV infections in the United States, approximately 63\% were among men who were infected through sexual contact with other men. ${ }^{30}$ However, black women are presumed to be at high risk of becoming infected with HIV from men. Men are tested for HIV less frequently and at later stages of their HIV infection, and are also less likely to have been previously aware that they were HIV positive. The television news story, "Out of Control: AIDS in Black America," which aired in August 2006, reported the

\footnotetext{
${ }^{25}$ Brodie et al., "AIDS at $21, " 1-8$.

${ }^{26}$ Ibid.

${ }^{27}$ Ibid.

${ }^{28}$ L. Spence, "Episodic Frames and HIV/AIDS: The Media and African American Public Opinion," Political Research Quarterly 10 (2009): 1-12.

${ }^{29}$ Ibid.

${ }^{30} \mathrm{CDC}$. HIV Prevalence, Unrecognized Infection, and HIV Testing Among Men Who Have Sex with Men-Five U.S. Cities, June 2004April 2005. (U.S. Department of Health and Human Services, 2005).
} 
results of studies from the Universities of Chicago and North Carolina and shed light on a complex reality that helps explain why heterosexual transmission among African Americans is so common. The results show that black men are more than twice as likely as white men to have multiple female partners at the same time. ${ }^{31}$ More importantly, the results from these studies show that the rates of all sexually transmitted diseases are higher among African Americans than other groups. ${ }^{32}$

\section{CONCLUSION}

Media coverage is a critical tool in the fight against HIV in the African American community. Brodie et al. (2003) found that only $3 \%$ of stories in the media are about U.S. minorities with HIV. ${ }^{33}$ However, Spence (2009) argues that African Americans with HIV are garnering more media attention today than in past years due to increased rates of HIV infection in African Americans. ${ }^{34}$ A further increase in media attention and assurance of scientifically sound and culturally relevant messages will help educate
African Americans about the disease, reduce the stigma associated with it, and inspire African Americans to get tested and linked to care. Poor media coverage impedes awareness efforts that can lead to further spread of the virus. To control the further spread of HIV in a population at such high risk for contraction of the disease, it is important that media outlets fairly represent the diversity of the face of HIV and tells the truth about who is affected. Therefore, increasing media coverage on African Americans with HIV can help the community stay virusfree.

Address correspondence to: Edith M. Williams Institute for Partnerships to Eliminate Health Disparities Arnold School of Public Health University of South Carolina 220 Stoneridge Drive, Suite 208 Columbia, SC 29210

E-mail: willi425@mailbox.sc.edu

\footnotetext{
${ }^{31}$ T. Moran. "Out of Control: AIDS in Black America."ABC News. Aug. 24, 2006. <http://abcnews.go.com/Primetime/story? $\mathrm{id}=2346857 \&$ page $=2>$. (Last accessed on Aug. 11, 2010).

${ }^{32}$ Ibid.

${ }^{33}$ Brodie et al., "AIDS at 21," 1-8.

${ }^{34}$ Spence, "Episodic Frames and HIV / AIDS," 1-12.
} 